\title{
Correction to: Phenomenon and experience: searching for the civilian in an age of remote warfare
}

\author{
Aditi Gupta ${ }^{1}$
}

๑) Springer Nature Limited 2021

\section{Correction to: International Politics https://doi.org/10.1057/s41311-021-00349-6}

The original article was published with incorrect affiliation of the author. The correct affiliation is All-Party Parliamentary Group on Drones and Modern Conflict, House of Commons, Westminster, SW1A 0AA.

The original article has been corrected.

Publisher's Note Springer Nature remains neutral with regard to jurisdictional claims in published maps and institutional affiliations.

The original article can be found online at https://doi.org/10.1057/s41311-021-00349-6.

Aditi Gupta

guptaab@parliament.uk

1 All-Party Parliamentary Group on Drones and Modern Conflict, House of Commons, Westminster, London SW1A 0AA, UK 